\title{
EFFECTIVE COST ANALYSIS TOOLS OF THE ACTIVITY-BASED COSTING (ABC) METHOD
}

\author{
Sorin Briciu ${ }^{1}$ \\ Sorinel Căpuşneanu ${ }^{2}$
}

\begin{abstract}
This article focuses on cost analysis and specific tools of Activity-Based Costing $(A B C)$ method. After presenting the main categories of operating costs of $A B C$ method it is switching to presenting the most important tools for monitoring and measuring performance, such as the dashboard, balanced scorecard, benchmarking etc. Components and benefits and the presentation of these situations are highlighted. The article ends with the conclusions of authors about analysis of these instruments also the advantages of them, the authors advocating the use of these types, since they represent advanced cases of analysis of performance derived from an asset that unit would be successfully applied in Romania.
\end{abstract}

Key words: dashboard, balanced scorecard, benchmarking, Activity-Based Costing, performance.

JEL Codes: M21, M41

\section{Introduction}

The article concerns the question of classification of costs according to the Activity-Based Costing method using specific tools for the analysis of costs. The criteria used are intended to clarify the types of costs used by $\mathrm{ABC}$ method and informational opportunities they provide for their analysis and use in decision making in the short or long term. Costs importance is significant to the extent that relevant costs are obtained and their use contributes to the preparation of summary and analysis of situations such as dashboard, balanced scorecard, benchmarking and others.

\section{Description of current state of knowledge}

In the literature, most experts have identified as a suitable method of obtaining high performance, the Activity-Based Costing method (ABC). Cost analysis tools used are different and the specific tools of $\mathrm{ABC}$ method are discussed especially in foreign literature. In Romania, most specialists in the field of management accounting have described broadly the monitoring and measuring enterprise performances tools, but the authors of this paper are intended to highlight first, the quality and relevance of information obtained by using three major cost measuring tools of the $\mathrm{ABC}$ method, i.e. dashboard, balanced scoreboard and benchmarking, and secondly, to present the advantages of using them also on short and long term.

\section{Types of costs used by ABC method}

Activity-Based Costing method uses the following types of costs: production cost, fixed cost, variable cost, total cost, direct cost, indirect cost (overhead). Correct determination of production cost requires appropriate monitoring of consumption of inputs used by an enterprise. Management accounting is able to highlight these issues and to record them in a timely manner and in their entirety, thereby providing accurate financial statements that enable the management to make effective decisions. Determination of production cost is based on the one hand, the breakdown

\footnotetext{
${ }^{1} 1$ Decembrie 1918 University, 11-13 N. Iorga Street, Alba-Iulia, sbriciu@yahoo.com

2 Artifex University, 47 Economu Cezarescu Street, Bucharest, sorinelcapusneanu@ gmail.com
} 
of production and on the other hand, activities classification specific to Activity-Based Costing method.

Production cost is represented by the sum of expenditure, as the expression value of consumption of inputs made during the manufacture of a product, execution of works or provide a service. Production cost is given by the sum of costs incorporated. Given the issues highlighted in the definition of production cost is necessary to make a classification of expenditures that are used in production cost.

The principle behind the $\mathrm{ABC}$ method is as follows: products consume activities, which in turn consume resources and these resources are aggregated because they constitute a cost. In determining the production cost we need both financial information and information about products and customers. Running $\mathrm{ABC}$ method involves attending three fundamental sub stages to observed, as follows (fig. no. 1.):

1. Identifying the resources ${ }^{3}$ consumed by internal activities;

2. Resource assignment on activities;

3. Identification of consuming activities (by product or customer).

We support the general process of summarizing that identifies the elements and necessary steps of cost calculation.

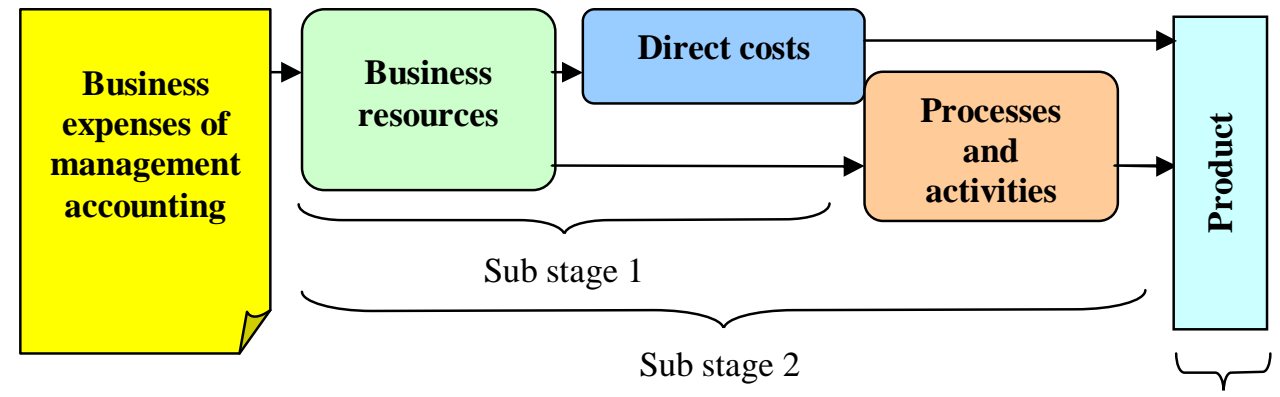

Sub stage 3

Fig. no. 1. - Scheme for determining the $\mathrm{ABC}$ production cost

An expense is incurred when a resource is done on its use in selection and activity level where it is engaged. The two concepts (resource and cost) reflect different accounting content, as is apparent in the following scheme (fig. no. 2.):

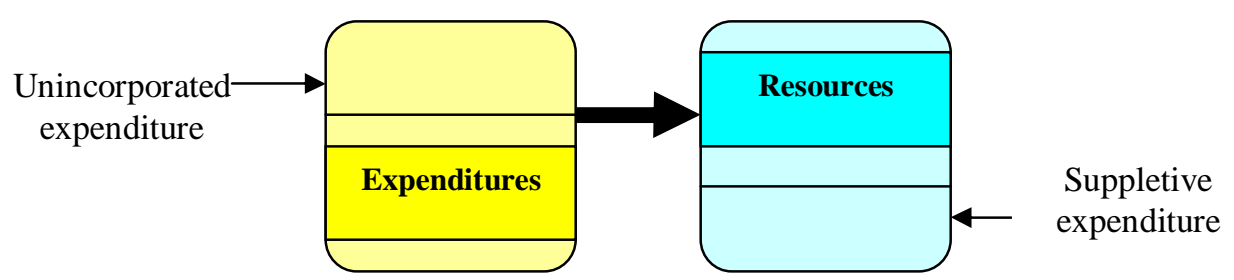

Fig. no. 2. - The way of inclusion of expenditures into costs

The French accounting are provided only two such expenses referred as suppletive (by definition they represent those costs which take into account the analytical accounting, but they are not in general accounting), namely: compensation of individual entrepreneur (manager) and pay equity. In the German accounting, all production costs have not been committed or that have not occurred are delineated by cost category calculations costs (accounting). Besides those mentioned

\footnotetext{
${ }^{3}$ Resources - a term used to mean spending. It is necessary to move from the concept of financial accounting expense, the concept of resources, based on their values in management accounting. This term is compatible with the logic of action and the trend of Activity-Based Costing (ABC) method.
} 
above under German accounting may include: rents, interest on equity, risks, depreciation and interest on foreign capital.

Many of the expenses will be excluded from the calculation because dress an extraordinary character and would aggravate so comparisons over time, for example, losses on the disposal of assets or depreciation of formation expenses. Another reason for which some expenditure is excluded is that they do not relate to the activities examined, for example: provision for impairment of investment securities and financial expenditure. Their awareness of late also causes their exclusion (e.g. provisions for uncertain customers). Some expenditure will be retained, but in a different time from appearing in the general accounting, for example, the depreciation expenditure will not be considered permissible value tax, but assessed in an economic optical or displayed while regularly to facilitate comparisons.

$\mathrm{ABC}$ method also treats the issue of incorporated expenditure, non-incorporated expenditure and that suppletive expenditure, being highlighted and the implications for the results (table no. 1.), the following manner:

\section{Treatment of expenditures according to the $\mathrm{ABC}$ method}

Table no. 1

\begin{tabular}{|c|l|l|}
\hline $\begin{array}{c}\text { Type of } \\
\text { expenditure }\end{array}$ & \multicolumn{1}{|c|}{ Treatment of the ABC method } & \multicolumn{1}{|c|}{ Observations } \\
\hline Incorporated & $\begin{array}{l}\text { Incorporated expenditure are included in the final } \\
\text { production cost of manufactured goods, performed } \\
\text { works or rendered services. }\end{array}$ & $\begin{array}{l}\text { Refers to operating expenses and those with long-term } \\
\text { borrowing credits. }\end{array}$ \\
\hline $\begin{array}{c}\text { Non- } \\
\text { incorporated }\end{array}$ & $\begin{array}{l}\text { Non-incorporated expenditure is taken out because it } \\
\text { reflects economic reality. }\end{array}$ & $\begin{array}{l}\text { This was the case of an extraordinary provision, the } \\
\text { accounting costs arising from an investment made by } \\
\text { anticipation. Directly reflect the overall result of the } \\
\text { company. }\end{array}$ \\
\hline Suppletive & $\begin{array}{l}\text { Suppletive expenditure is added to be recorded in the } \\
\text { year they were employed. They are, for example, } \\
\text { research and development expenditure incurred for } \\
\text { the current sales of products or even the difference } \\
\text { between economic depreciation and accounting } \\
\text { depreciation. }\end{array}$ & $\begin{array}{l}\text { This technique, which is not new, often introduces a split } \\
\text { between financial accounting and management } \\
\text { accounting. ensure consistency of information is clearly } \\
\text { To arranted a better understanding of them. Indirectly } \\
\text { reflected in company results. }\end{array}$ \\
\hline
\end{tabular}

Non-incorporated expenditure and suppletive expenditure are two distinct concepts that are on the border of expenditure of general accounting and the expenditure incorporated into the costs. This takes only asset that each unit knows the implications of these expenditures and can choose one category or another in their inclusion in costs. Accounting treatment differences drives the difference between the result of general accounting and overall analytical result.

In terms of economic content production costs, particularly in the $\mathrm{ABC}$ method two categories of expenditures: raw materials expenditures and salaries expenditures.

Raw materials expenditures are represented by objects of labor consumption (consumption of raw materials and direct materials). Salary expenditures are represented by use of human labor (wages owed to staff salaries and accessory unit ${ }^{4}$ ).

In terms of inclusion in the cost calculation object, we distinguish: direct expenditures and indirect expenditures.

Direct expenditures are that category of expenditures which may include the direct cost of production, because it presents the possibility of identifying the object of direct calculation (products, works, services, orders etc.).

Indirect expenditures are that category of expenditures that are not included directly in the calculation of the cost object, but it relies on an appropriate allocation of cost carriers using specific cost inductors. In other words they can not directly identify the bearers of costs, but collected on activities and then allocates the objects of calculation, taking into account the cost carefully selected

\footnotetext{
${ }^{4}$ The accessory unit means social security contributions, unemployment fund, health fund etc.
} 
cost drivers. Depending on the destination that receives expenditures are divided into: business expenditures and activities expenditures.

Process expenditures include all resources identified by way of structuring the company's processes. This corresponds typically enterprise functions such as purchasing, production, sales, marketing, administration, quality control etc.

Activities expenditures include all those expenses which were allocated a certain percentage of some business process.

Depending on the behavior they have in allocating costs on business processes, we distinguish: fixed costs and variable costs.

At process level both categories of expenditure are identified, taking into account the received destination in the allocation moment from financial accounting into the management accounting.

In terms of visibility when the resource allocation cost objects using cost drivers, all fixed costs become variable in the short term, if carefully investigate the cause or origin. Variability of costs is given by the proximity to customers, the degree of complexity or their development period. This treatment of the $\mathrm{ABC}$ method is the most important contribution in solving the allocation of fixed costs on cost objects.

\section{Measuring and performance monitoring tools of the ABC method}

Transforming the obtained data from the process and activities flows into useful information requires the use of analysis tools that apply the $\mathrm{ABC}$ method characteristic information. There are several specific tools that can be used as accessories, stimulating creativity and imagination in development of original ideas and that are working to highlight the achievement of enterprise-level performance. Among these tools we can mention: the dashboard, balanced scorecard, benchmarking, self-assessment, diagnostic analysis, cost-profit etc.

Dashboard is a way of framing, selection, arrangement and presentation of indicators, which allows visualization of overall trends in development pursued by the company management by objectives. Dashboard includes that indicators system expressed in absolute and relative size, used for evaluation, control and operative regulation of business activity. Under the $\mathrm{ABC}$, dashboard objectives aimed:

- Developing analysis useful for business strategies;

- Optimization of each function of the enterprise by optimizing the operation of each component service.

At the basis of dashboard are the following principles:

1. The principle of consistency and relevant information. According to this principle, the information it provides a dashboard must respect the hierarchical lines of business established in accordance with enterprise establishment and its transversal organization. Dashboards elaboration at department's level with identical functions concentrates information based on the same definition and measurement of performance indicators, using a common database. The information contained on the dashboard as indicators must be relevant, to adequately reflect reality and serve to take suitable decisions. Number of selected indicators and concentrated around performance decision centers must be rational, so that the information obtained is relevant and concise, summarized and adapted for hierarchical levels.

2. The principle of efficiency provided information. According to this principle, the information contained in the dashboard must be analyzed and interpreted (particularly negative deviations) and designed a series of corrective actions and measures for their implementation.

3. The principle of standardization information. According to this principle the information refers to fixed objectives, previous results and working hypotheses. On that basis it determines, calculate report and interpret deviations obtained at the department's levels or work centers. 
4. The principle of frequency for obtaining and disseminating information. How to draw and disseminate information within dashboards during decision-making depends on the departments concerned or the management level. In other words, reliability and rapid production and dissemination of the dashboards by the decision-making entitled persons, influence the way of making decision and ultimately the success or failure of business enterprise.

Dashboard presents in its composition: the stock tables, graphs or the combination of the mentioned two. The form it may take a dashboard can be (fig. no. 3.):

\begin{tabular}{|c|c|c|c|c|c|}
\hline $\begin{array}{l}\text { STRATEGIC DASHBOARD } \\
\text { organization process Production }\end{array}$ & Dashboard & Cost drivers & Objjectives Annalysis & Annalytic al views klodels $^{\text {Registration | Phout.. }}$ & Registration | Pbout ... \\
\hline \multirow{9}{*}{$\begin{array}{l}\text { ComponanTs } \\
\text { Activity-Based Costing } \\
\text { q Strategic dashboard } \\
\text { Q Operational dashboard } \\
\text { Q Activities list } \\
\text { - } 110 \text { Finance } \\
120 \text { Harket } \\
123 \text { Order } \\
130 \text { Production } \\
\text { Q Strategy map definitions }\end{array}$} & \begin{tabular}{|l|l|} 
Dashboard & V \\
\end{tabular} & Dashboard dimension & IV March 2010 & \begin{tabular}{|l|l|l|} 
IV Actual Plan & V \\
\multirow{20}{*}{$: 0 \% \%$} & V \\
\end{tabular} & $\Delta$ \\
\hline & \multicolumn{5}{|c|}{ TABLOU DE BORD STRATEGIC } \\
\hline & \multicolumn{5}{|c|}{$\begin{array}{l}\text { Dashboard situation } \\
\text { Domestic impact of launching a new range of influences on the personnel issue, } \\
\text { customer demand and revenue cash-How influence }\end{array}$} \\
\hline & $\begin{array}{l}\text { - } 0 \% \\
\text { Learning and growth }\end{array}$ & - $37 \%$ External & - $20 \%$ Customers & T3\% & \\
\hline & $\begin{array}{l}\text { Mofivated and competent } \\
\text { employees }\end{array}$ & Wortd chass supply chain & $\begin{array}{l}\text { Satisfied custumers and } \\
\text { dealers }\end{array}$ & Good result and cash low & \\
\hline & $\begin{array}{l}\text { Hotivated and prepared } \\
\text { work force } \\
0 \%\end{array}$ & $\begin{array}{l}\text { Effective and punctual } \\
\text { innovating process } \\
10 \% \%\end{array}$ & $\begin{array}{l}\text { Increase customer } \\
\text { satisfaction } \\
102 \%\end{array}$ & $\begin{array}{c}\text { Cregstere cashflow } \\
\qquad 4 \%\end{array}$ & \\
\hline & $\begin{array}{l}\text { - INlok environment } \\
\text { Sick absence } \\
\text { - Overtime } \\
\text { - Staff tumover }\end{array}$ & $\begin{array}{l}\text { - Productlaunches } \\
\text { - Tumover of neviproducts }\end{array}$ & $\begin{array}{l}\text { Customer satisfaction } \\
\text { - Buyny different product } \\
\text { - Number of order lines }\end{array}$ & $\begin{array}{l}\text { - Customer at tirk } \\
\text { Revenue margin }\end{array}$ & \\
\hline & $\underset{0 \%}{\text { Right competencies }}$ & $\begin{array}{c}\text { Operation al excellence } \\
23 \%\end{array}$ & $\begin{array}{c}\text { Improve customer } \\
\text { relations } \\
106 \%\end{array}$ & $\begin{array}{c}\text { Revenue growth } \\
132 \%\end{array}$ & \\
\hline & $\begin{array}{l}\text { - Education hour's staff } \\
\text { - Education meeting }\end{array}$ & 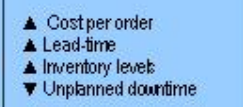 & $\begin{array}{l}\text { A Up.to-date infomation } \\
\text { No. of retums } \\
\text { \& No. of complains }\end{array}$ & $\begin{array}{l}\text { Total revenue } \\
\text { A No. of customer prospects }\end{array}$ & \\
\hline
\end{tabular}

Fig. no. 3. - Dashboard situation

Piloting indicators are information elements representative in relation to objectives, resulting in tangible measurement or observation of conditions, events or developments. The improvement performance objectives may be of different types. Thus we can distinguish the following typology: objectives related to volume or level of activity, effectiveness and efficiency objectives, quality objectives (or non-quality), cost goals, objectives related to delivery time.

Piloting indicators is therefore a useful data source for all hierarchical levels. Each of the pilot branch out into specific indicators which are as follows:

- Piloting indicators of activities and processes that measure the actions carried out within operational services to achieve the defined strategy;

- Strategic piloting indicators that measure the action against competitors and competitive environment;

- Piloting indicators of results which measure the degree of fulfillment of the operation objectives.

Information covering with specific indicators of these three areas provides a firm coherent and comprehensive system of pilotage. These types of indicators are composing the full dashboard of manager and his collaborators. Permanent knowledge of the status and progress indicators provided within dashboards oriented objectives allows management to improve enterprise performance. The information content of dashboards should be made known to other departments or 
functional services, just as the final decision will be taken at management level to be based as closely, and the difficulty of the decision to consider the opinions and conclusions of all those involved in the smooth running of the business.

For example, in the Activity-Based Costing (ABC) method, all enterprise resources are consumed by the activities. It is very important that studied indicators to cover the whole enterprise area. Identification of relevant indicators for measuring enterprise performance are suggested and determined primarily by the level of activities. For most companies it was found out that the indicators are focused primarily on direct labor, which is particularly important in all used resources. But labor costs are also reflected in the production, marketing or administration.

Generally speaking, the activities of an enterprise are evaluated using the ABC method (Activity-Based Costing) through indicators such as: activity level, costs, effectiveness, efficiency, quality, non- quality etc. They will be established and followed monthly through Specification of Indicators. By way of example, levels of activity indicators are followed to their objective value. Efficiency and effectiveness indicators are compared with the objectives. Finally, quality indicators help to compare the reliability of activities compared to total quality objective.

According to specialists, we can identify several categories of indicators such as:

1. Indicators related to volume or activity level. These indicators express the volume of work produced during a defined period or same estimated objective. They measure in an improvement optical the activity level (generally the number of "outputs" provided). It may take into account the number of contacts with customers, suppliers, internal and external collaborations, supplies (monthly or quarterly), etc. made by an enterprise. The purpose of these indicators is to reveal the volume drawn from contacts with partners within a defined time (monthly or quarterly). It also may consider longer periods of time (e.g. 1 year), but the results are intended to be short term to make decisions as fast and efficient. General form that can take these indicators is as follows:

$$
\frac{\text { Cost driver }}{\mathrm{N}} \text {, where: } \mathrm{N}=\text { number of time periods. }
$$

2. Indicators related to objectives of efficiency and effectiveness. Summary of defining the two concepts is based on the difference between them. Efficacy is the ability to obtain the desired objectives, while efficiency is the ability to minimize the employee's media for a given a result. In other words, efficiency helps us know the results of objectives, while that efficiency helps us to know whether the objectives are met in relation to the original set budget.

Indicators related to objectives of efficiency reflect the changes in turnover to changes of cost drivers used by an enterprise. General form that can take these indicators is as follows:

$$
\mathrm{I}_{\text {efficacy }}=\frac{\overline{\mathrm{T}}_{\mathrm{N}+1}-\overline{\mathrm{T}}_{\mathrm{N}}}{\overline{\mathrm{T}}_{\mathrm{N}}} x 100 \text {, where: } \overline{\mathrm{T}}=\frac{\mathrm{T}}{\text { Cost driver }}
$$

Where: $\overline{\mathrm{T}}=$ Average turnover per order; $\mathrm{N}=$ number of time periods.

Subunit efficacy indicators signify the company's ability to successfully meet objectives (positive deviation) while over unit efficacy indicators indicates the enterprise failure to achieve business goals (negative deviations in case of failure of objectives).

Indicators related to objectives of efficiency reflect hourly changes to changes of cost drivers used by an enterprise. General form that can take these indicators is as follows:

$$
\mathrm{I}_{\text {efficiency }}=\frac{\overline{\mathrm{V}}_{\mathrm{N}+1}-\overline{\mathrm{V}}_{\mathrm{N}}}{\overline{\mathrm{V}}_{\mathrm{N}}} x 100 \text {, where: } \overline{\mathrm{V}}=\frac{\mathrm{V}}{\text { Number of orders }}
$$

where: $\bar{V}=$ volume average hours per order; $N=$ number of time periods.

Subunit efficiency indicators express the enterprise inability to achieve business objectives in quantitative terms (negative deviations), while over unit efficiency indicators means the enterprise ability to achieve business goals (positive deviations). 
3. Indicators related to objectives of quality (or non-quality). These indicators measure the level of reliability (or non-reliability) of an activity for the purpose of total quality. It serves for the calculation of non-quality costs. Form they may take these indicators are as follows:

$$
\frac{\text { Cost driver (1...n activity) }}{\text { Cost driver (objective) }}
$$

Where: $1 \ldots n$ activity $=$ activity number from the list (activities catalog, objective $=$ total quality $(100 \%)$.

4. Indicators related to objectives of cost. These indicators will measure the cost and evolution of resources consumed by an activity. They allow studying the possible outsourcing of sub activity. General form that can take these indicators are as follows:

$$
\frac{\text { Cost }}{\text { Cost driver }}
$$

where: cost $=$ cost of an activity; cost driver $=$ the allocation base of specific product.

5. Indicators related to objectives of delivery terms. These indicators measure the delays to achieve a benefit and as such, participate in the measurement of normal value of customers. General form that can take these indicators can be expressed as:

$$
360-\left(\frac{\text { Customer invoice value }}{\text { Customer turnover }}\right) \times 360
$$

For example, late deliveries are distinguishing features of the customers. At an equal price between two suppliers, a customer will choose the company that deliver as soon as possible. It certainly helps to:

1. Distinguish those delays in the success key factors of that market;

2. Identify the strengths and weaknesses in relation to competitors;

3. Improving speed of delivery delays competing activities in a logical process;

4. Progress measure using indicators related to time of delivery;

\begin{tabular}{|c|c|c|c|c|c|}
\hline \multicolumn{2}{|c|}{ Indicators } & \multicolumn{4}{|c|}{ Stages } \\
\hline $\begin{array}{l}\text { Type of } \\
\text { indicator }\end{array}$ & Name of indicator & Observations & $\begin{array}{c}\text { Cause (negative) } \\
\text { identified }\end{array}$ & $\begin{array}{c}\text { Cause (positive) } \\
\text { identified }\end{array}$ & Actions \\
\hline $\begin{array}{l}\text { Volume } \\
\text { activity } \\
\text { indicator }\end{array}$ & $\begin{array}{c}\text { Rates of new } \\
\text { customers attracted by } \\
\text { the company }\end{array}$ & $\begin{array}{l}\text { Inferior rate in comparison } \\
\text { with objective }\end{array}$ & $\begin{array}{l}\text { - Customer focus } \\
\text { - No longer offer } \\
\text { products according to } \\
\text { customer requirements }\end{array}$ & $\begin{array}{l}\text { Market penetration is } \\
\text { important }\end{array}$ & $\begin{array}{c}\text { - Customers re- } \\
\text { segmentation } \\
\text { - Development of new } \\
\text { products }\end{array}$ \\
\hline Cost Indicator & $\begin{array}{l}\text { The cost of activity } \\
\text { "market development } \\
\text { of high tension" }\end{array}$ & $\begin{array}{l}\text { Part of the cost of the } \\
\text { activity is increasing in } \\
\text { relation to turnover of the } \\
\text { sector }\end{array}$ & $\begin{array}{l}\text { - Turnover selling } \\
\text { point average is } \\
\text { declining } \\
\text { - Insufficient new } \\
\text { customers }\end{array}$ & Pressure on prices & $\begin{array}{l}\text { - Adapting to the new } \\
\text { trade action data } \\
\text { acquisition } \\
\text { - Adapt offers better } \\
\text { prices through cost } \\
\text { approach } \\
\text { - Adapting traders pay }\end{array}$ \\
\hline $\begin{array}{l}\text { Effectiveness } \\
\text { indicator }\end{array}$ & $\begin{array}{l}\text { Turnover average } \\
\text { selling point }\end{array}$ & $\begin{array}{c}\text { Target compared with } \\
\text { turnover in terms of sales } \\
\text { stagnate }\end{array}$ & $\begin{array}{l}\text { - The proposed product } \\
\text { range is too small } \\
\text { - Insufficient number } \\
\text { of products }\end{array}$ & $\begin{array}{l}\text { A part of the market } \\
\text { respond in relation to } \\
\text { the current range }\end{array}$ & $\begin{array}{l}\text { - Wider range of } \\
\text { products offered in } \\
\text { midrange products } \\
\text { - Development of a } \\
\text { assembly concept }\end{array}$ \\
\hline
\end{tabular}

5. Highlighting this element of differentiation to customers (normal quality).

Table no. 2

Analysis of dashboard indicators

Balanced Scorecard is composed from a set of related indicators of business strategy and enables possibility of piloting performances on its components, combining the traditional financial instruments with the non-financial instruments and providing managers relevant information on the activities conducted by them. According to its authors, Robert Kaplan and David Norton, the dashboard is a balanced strategic approach but also a performance management system that allows organizations to translate visions and strategies into action, in terms of four perspectives: financial, customer, learning and growth and internal business. 


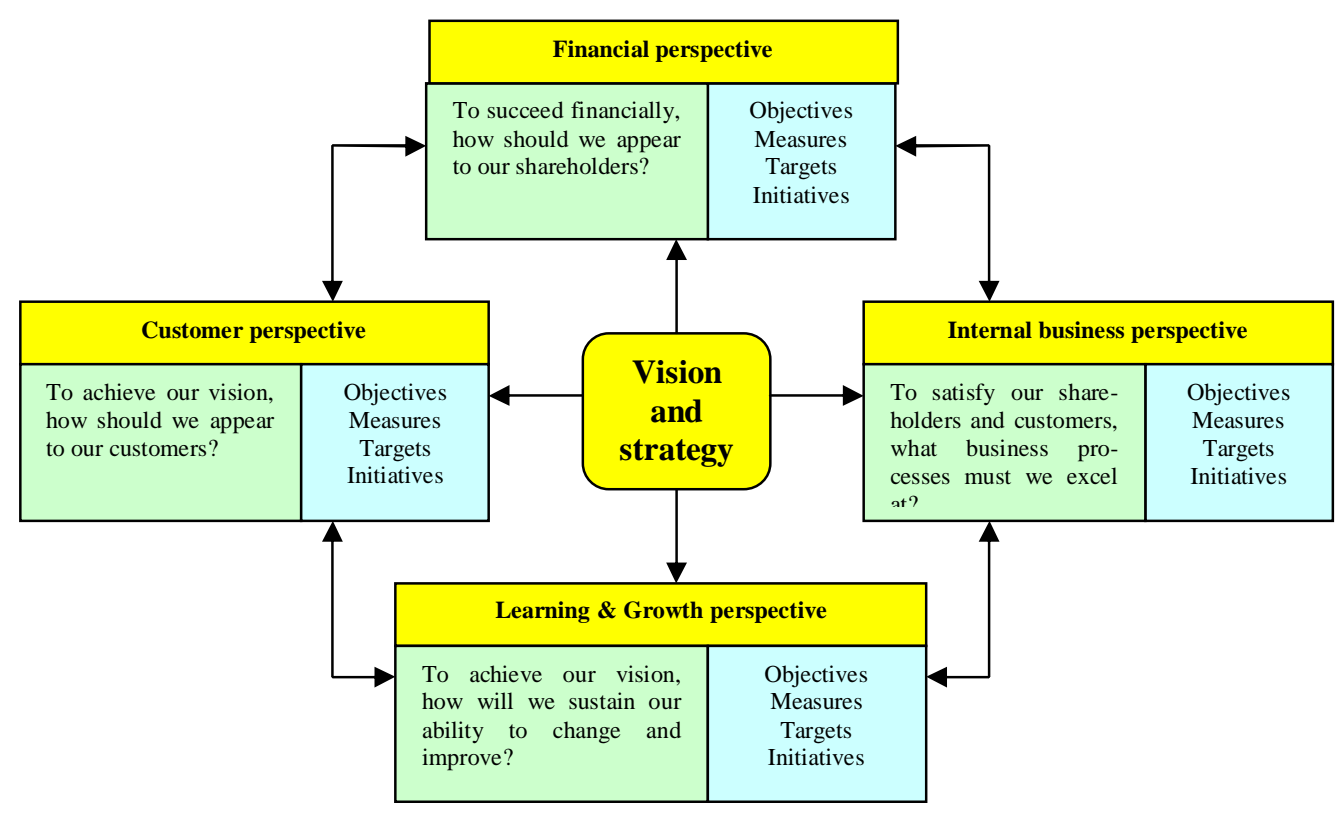

Fig. no. 4. - The balanced scorecard

Adapted from Kaplan and Norton, 1996, The Balanced Scorecard, Harvard Business Press: 9, Original from HBR Jan/Feb, 1996, p. 76.

1. Financial perspective. As is apparent, Kaplan and Norton do not disregard the traditional need for financial information. Basic information obtained in a useful time will always be a priority, and managers will do whatever is necessary to provide them. In fact, it is often more than enough handling and processing of financial data. With the implementation of a corporate database, it is hoping that more data processing can be centralized and automated. But the idea is that the current emphasis placed on financial statements creates a "lopsided" situation, on the other perspectives. There is probably a need to include additional financial data in this category, such as risk assessment, gross margin, net earnings or cash-flow.

2. Customer perspective. Recent management philosophy has shown an increasing realization of the importance of customer orientation and customer satisfaction in any business, they are indicators of success. If customers are not satisfied, they will eventually find other suppliers that will meet their needs. Poor performance from this perspective is a leading indicator of future decline, even if current financial picture might look better. In developing metrics satisfaction, customers should be analyzed in terms of types of customers and types of processes, for offering a product or service to these customer groups.

3. Internal business perspective. Measurements based on this perspective allow the managers to know how well they run their business, and if their products and services comply with customer requirements. These measurements must be carefully drafted by those who know these processes in the smallest details. In addition to the strategic management process, two kinds of internal processes can be identified:

a) Process-oriented mission;

b) Support processes.

Mission-oriented processes are special features of governmental offices and many unique problems are encountered in these processes. Support processes are more repetitive in nature, and therefore more easily measured and compared using generic metrics.

4. Learning \& Growth perspective. This includes both employee training and cultural attitudes about self-improvement of individual and corporate. In a knowledge-based worker 
organization, people are the main resource. In the current climate of rapid technological changes becomes necessary for known workers to be in a continuous learning process. Kaplan and Norton emphasizes that "learning" is more than "training." This includes also mentors and tutors within the entity, and that facilitates communication among workers, allowing them to easily obtain help in a problem when needed. May also include, technological tools such as intranet. The form it may take a balanced scoreboard is as follows:

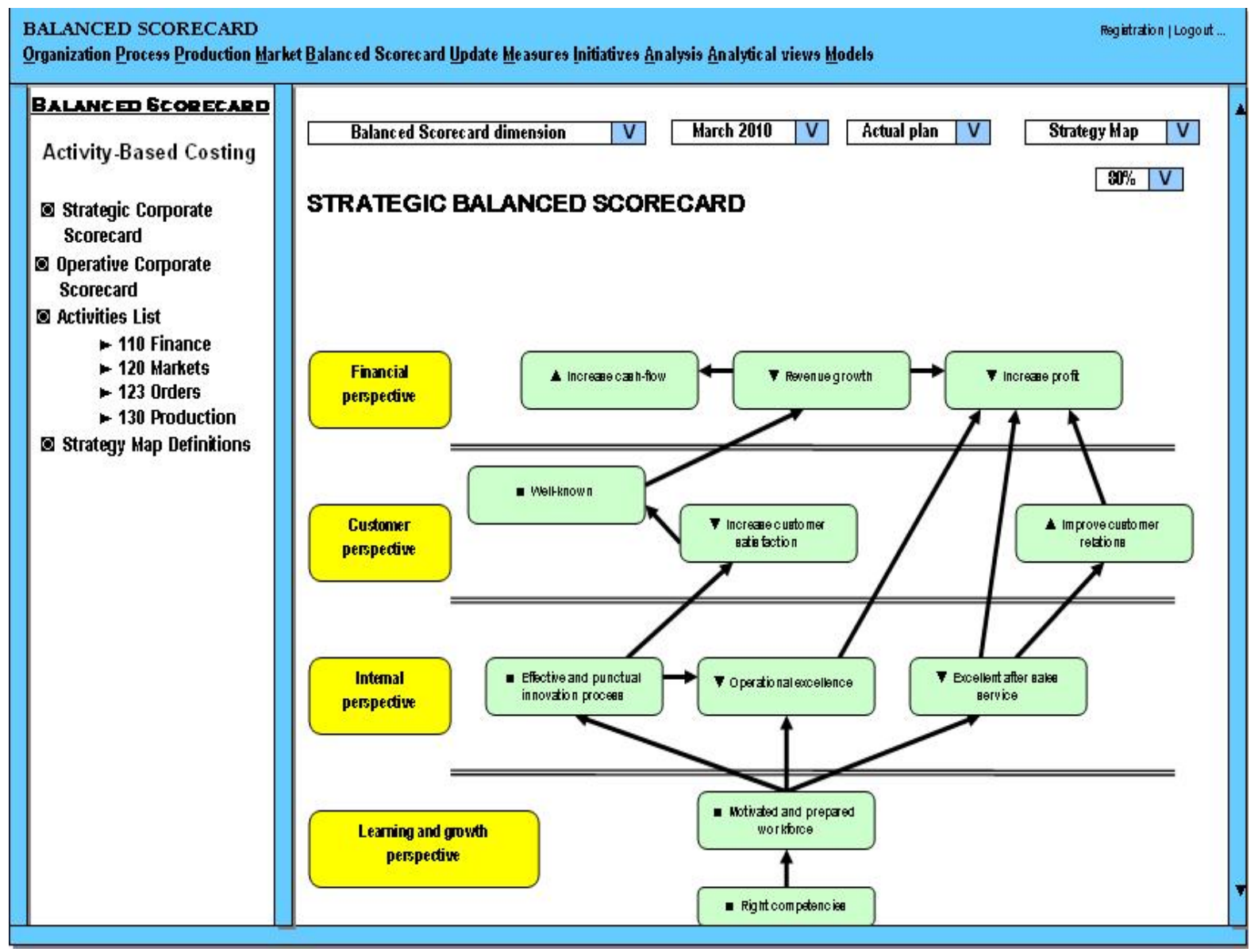

Fig. no. 5. - Strategic balanced scorecard

Benchmarking or comparative analysis is the process by which an entity compares its practices performance with those of one or more entities. Its objective is to identify best practices that will improve its performance. In other words, for an entity, benchmarking is a selfimprovement tool that enables it to compare with other competitors and thus to identify its strengths and weaknesses and learn how to improve them.

Benchmarking is a performance or functional objective that allows achieving an excellent level of quality, delivery, cost and speed. It is necessary for processes, products or services to be measured against other processes, products or services recognized as the best in the world.

Benchmarking is a structured approach that involves collecting data (via a questionnaire), analysis and reporting. The questionnaire may require qualitative or quantitative data or a combination of both. Data collection can range from simple on-site visits (time consuming) to poll online type (much faster). Result analysis of data is a benchmark against which to compare the entity's performance and target improvements. In this way benchmarking helps explain the processes behind performances. If the lessons learned from the benchmarking exercise are applied appropriately, they facilitate improved performance in critical functions within an entity or key business areas respectively. 
Application of comparative analysis involves four main steps:

1. Understanding in detail the internal processes;

2. Analyzing the internal processes of other entities;

3. Comparing their performance with the consideration of other entities;

4. Application of necessary measures to eliminate the performance gap.

Benchmarking should not be considered as an exercise to be carried out once. To be effective, it must become an integral part of continuous improvement process in order to keep abreast of industry best practices.

The costs of comparative analysis

In the comparative analysis are included three major categories of costs: labor time.

1. Visit costs include costs related to: accommodation, travel, meals, symbolic gifts and lost

2. Costs of extra time (additional time). Conducting benchmarking team will invest additional time in research problems, finding exceptional companies to study, visit and apply.

3. Database costs associated to comparative analysis. Organizations that use benchmarking in their daily procedures find it useful to create and maintain a database of best practices and their associated companies.

Comparative analysis of costs can be reduced considerably by using multiple Internet resources that have emerged over recent years. These benchmarks follow and capture best practices from countries, entities, business sectors to make the benchmarking process much faster and cheaper. The form it may take benchmarking is as follows:

\begin{tabular}{|c|c|c|}
\hline Bienchmarting & Period: 3months & 6 months 1 year \\
\hline & & C. $x$..... Warket \\
\hline Sauingspend (fir) & $2,4 \%$ & $19,5,5$ \\
\hline \multicolumn{3}{|l|}{ Requests } \\
\hline Free tormequesta( $(\%)$ & 45 FAd & $10, \%$ \\
\hline Requesta a provol (dayal) & 11 alde & 4 are \\
\hline Rejection[\%o $]$ & $8,5 \%$ & $10,3,4$ \\
\hline Self-approval[(naj) & $7,5 \%$ & $30, x_{10}$ \\
\hline $\mathrm{RFQ}(\%)$ & $2,3 \%$ & $9, \%$ \\
\hline \multicolumn{3}{|l|}{ Orders } \\
\hline A we rage fo Va lus (Euro) & 10000,0000 & NW. \\
\hline Purcteased Ordara baved & 105 & NA. \\
\hline Active s uppliars [\%] & $75,2 \%$ & $569, \%$ \\
\hline FQ revisiore (Th) & $5,5 \%$ & $5,3 \%$ \\
\hline Proards a pand ( $\left(T_{a j}\right)$ & $0,0 \%$ & $4,5, \mathrm{w}$ \\
\hline Active supplisa [ [\%] & $25 \%$ & NAS \\
\hline \multicolumn{3}{|l|}{ Invoices } \\
\hline Aprroved inroices & 4896 & NAS \\
\hline E-Imwoicos( & $0,0 \%$ & 20,5 \\
\hline Invoise hold (\%ib) & $54,5 \%$ & 23,5 \\
\hline Time to retzas to kds [daye] & 1 minut & NWS. \\
\hline Non-mate hed invo bee [\%] & $1,5 \%$ & $12,5, \%$ \\
\hline Voida $\left[\Phi_{0}\right)$ & $0,0 \%$ & NAS. \\
\hline
\end{tabular}

Fig. no. 6. Benchmarking 


\section{Conclusions}

The three instruments have examined present a number of advantages which it recommends as one of the most effective tools for monitoring and measuring performance of the Activity-Based Costing method (ABC) and beyond, they are the real foundation on which decisions are taken by the management of the enterprise. Thus among the advantages of the dashboard and balanced scorecard, we can mention:

- Taking into account the four different perspectives of the balanced scorecard and viewing them as a whole, the management company is ensuring for a balanced perspective on its performances;

- Short, medium and long term visions are continuously managed, cohesive both on the dashboard and the balanced scorecard;

- The strategies made by senior management and actions taken at the department's level are focused and clearly linked;

- The company performance reporting is focusing on the needed aspects to remain competitive in the long term and reflecting the achievement of value for stakeholders.

Among the benchmarking advantages we can mention: identifying areas for improved performance, identify risks, contributing to continuous improvement, meeting audit requirements, compliance and regulatory authority, monitoring and reviewing progress, improving quality.

In the hope that our perspective on the importance and effectiveness of performance analysis tools to specific $\mathrm{ABC}$ method was correctly received both in business and in academia, we express our desire to improve and broaden the scope of analysis these tools by extending collaboration in training, the dissemination of results of scientific research in this area is particularly important as management accounting.

\section{References}

1. Atkinson A.A., Banker R.D., Kaplan R.S., Young S.M., 2004, Management Accounting, Fourth Edition, Prentice Hall.

2. Briciu S., Căpuşneanu S., Rof L.M., Topor D., 2010, Accounting and management control. Entity performance assessment tools, Aeternitas Publishing House, Alba-Iulia, 2010.

3. Briciu S., 2006, Management accounting. Theoretical and practical aspects, Economic Publishing House, Bucharest.

4. Briciu S., Burja V., 2004, Management Accounting. Calculation and cost analysis, Ulise Publishing House, Alba Iulia.

5. Căpuşneanu S., 2008, Elements of cost management, Economic Publishing House, Bucharest.

6. Căpuşneanu S., 2006, Dashboard and Firms Performance Optimization Using Piloting Indicators, Theoretical and Applied Economics, no. 5, pp. 85-90.

7. Cokins G., 1996, Activity-Based Cost Management-Making it work - A manager's guide to implementing and sustaining an effective ABC system, The McGraw-Hill Companies, Inc.

8. Ravignon L., Bescos P.L., Joalland M., Bourgeois S.Le, Maléjac A., 2003, Méthode $\mathrm{ABC} / \mathrm{ABM}$, Ed. d'Organisation, Paris. 